\title{
Niklas Luhmann's Card Index: Thinking Tool, Communication Partner, Publication Machine
}

\author{
Johannes F.K. Schmidt \\ 12.1 The Sociology of Niklas Luhmann
}

Niklas Luhmann (1927-1998) taught at the Faculty of Sociology at the Bielefeld University (Germany) from 1969 until his retirement in 1993. He was one of the outstanding sociologists of the twentieth century, and one of the last advocates of a 'grand theory'. Over the course of his forty years of academic work, he developed a universal social theory that raised claims of being applicable to and capable of describing social phenomena of any kind: specific types of social systems such as face-to-face interactions, organizations, or society, social communication media such as trust, power, or love, or also matters of contemporary contents such as environmental issues, social movements, or processes of social exclusion. Since the beginning of his academic career in the early 196os, Luhmann published a bewildering wealth of articles and books year after year. At the time of his death, his list of publications comprised more than 500 titles. $^{1}$

Since then, a number of more recent monographs and articles have been published posthumously that had largely been completed at the time of his death, and there still are other manuscripts in his literary estate that he completed or are at an advanced stage but have not yet been published. ${ }^{2}$ All in all, this amounts to about 50 books and $55^{\circ}$ articles that have emerged from Luhmann's theory lab. This sheer number of publications is unprecedented in contemporary sociology. This amazing quantity is even topped by the range of subjects addressed in these publications that cover nearly the entire spectrum of social phenomena, which in itself is a unique achievement and in line with the goal that he set himself of developing a 'supertheory'.

1 See "Niklas Luhmann - Schriftenverzeichnis" in the sociological journal Soziale Systeme, 4 (1998), pp. 233-263.

2 In total, there exist more than 150 unpublished manuscripts. The Bielefeld University acquired Luhmann's literary estate in 2011. Since 2015, it is being prepared to make it accessible for research.

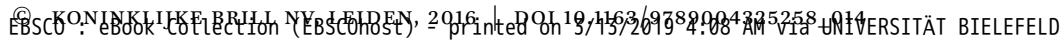
AN: 1368111 ; Cevolini, Alberto.; Forgetting Machines : Knowledge Management Evolution in Early Modern Europe 
A remarkable aspect in this respect is that the large number of publications and the great diversity of subjects covered therein are not the product of utilizing a plurality of different theoretical approaches depending on the research topic in question. Rather, all of this work was part and parcel of a comprehensive, coherent, and ongoing program of theory building by which Luhmann, who began his career in the field of jurisprudence, sought to radically expand the potential of sociology. In so doing, he placed great emphasis on conceptual and terminological consistency and, for this reason in particular, was receptive to theoretical developments in other academic disciplines such as philosophy, law, theology, biology, or cybernetics. Whereas his initial publication activities were more strongly focused on the fields of administrative and organizational studies, he turned to developing the key elements of his sociological work in the period from 1962 to 1997, which involved considerations on the methodological and theoretical foundations of a theory of social systems, a comprehensive theory of society, as well as studies on the link between the structures and self-description of modern society.

At a remarkably early point in his career - namely in the 1950s, before Luhmann had any institutional affiliation with academia but was still employed as a senior civil servant in public administration (höherer Verwaltungsdienst) ${ }^{3}$ he was conscious of the fact that the notes he took from his readings at the time, primarily in political science, public administration, and philosophy, would not be collected for a limited publication project but for a far more extensive endeavour. The shortcomings of some of the common methods of organizing notes by inserting them between the pages of books or collecting them in folders motivated him early on to start a card-based filing system. ${ }^{4}$ Apart from Luhmann's exceptional intellectual abilities, there can be no doubt that this specific filing technique, by which he systematically organized the results of his extensive readings across a broad range of disciplines, provided the foundation for his universal theory and vast number of publications. In Luhmann's own assessment, the large number and great diversity of publications would

3 At this time, he was working on his doctoral thesis in law, which he had largely completed in 1955 but did not submit.

4 "I started the index card file for the simple reason that I have a poor memory. Initially, I had started to insert slips of paper with the notes that I had taken into books. This led to damaging the bindings of the books. Then, I tried folders. As they became thicker, I couldn't find anything in them anymore. From $195^{2}$ or 1953 on, I started the index card file because it was obvious to me that I would have to plan for a lifetime not for a book". Cf. Niklas Luhmann, "Biographie, Attitüden, Zettelkasten", in N. Luhmann, Archimedes und wir. Interviews, ed. by D. Baecker and G. Stanitzek (Berlin: Merve Verlag, 1987), pp. 125-155, at p. 149 (all following citations of Luhmann's works are the author's translations from the German).

EBSCO : eBook Collection (EBSCOhost) - printed on 3/13/2019 4:08 AM via UNIVERSITÄT BIELEFELD AN: 1368111 ; Cevolini, Alberto.; Forgetting Machines : Knowledge Management Evolution in Early Modern Europe 
have been inconceivable without this filing system. "Of course, I do not think of all this on my own; it mostly happens in my file. ... In essence, the filing system explains my productivity. ... Filing takes more of my time than writing the books". ${ }^{5}$

In organizing his research in this way, Luhmann adopted a system of organizing knowledge that had emerged in the wake of early modern scholarship along with the rapidly growing number of available publications since the sixteenth century and the practice of excerpting that followed. ${ }^{6}$ He went on to develop to perfection the potential for systematic knowledge production ${ }^{7}$ inherent in this filing technique by devising a very specific system of organization and referencing that is unique in the history of the card-based filing systems that have been used in the social sciences and humanities in recent times - those of Claude Lévi-Strauss, Roland Barthes, and Hans Blumenberg come to mind here.

\subsection{Niklas Luhmann's Card Index}

The outer appearance of Luhmann's card index is far from spectacular, perhaps even rather disappointing on first glance considering the myth that surrounds it: it consists of only six small filing cabinets made of beech wood with four drawers each, no larger than a dresser in its entirety.

The true magnitude of the file becomes apparent only when opening the drawers: each drawer contains between 3,000 and 3,500 handwritten cards in A-6 format. As Luhmann sought to limit the size of the file so that he could work with it from his desk, he used simple paper, as thin as possible, instead of regular index cards. In many cases, he had cut sheets of paper to size himself that were initially A-4 size and had already been used on one side (often

5 Luhmann, "Biographie, Attitüden, Zettelkasten", p. $142 f$.

6 See Alberto Cevolini, "Verzetteln lernen. Gelehrsamkeit als Medium des Wissens in der frühen Neuzeit", Soziale Systeme, 10: 2 (2004), pp. 233-256; Helmut Zedelmaier, Bibliotheca universalis und Bibliotheca selecta. Das Problem der Ordnung des gelehrten Wissens in der frühen Neuzeit (Weimar et al.: Böhlau, 1992), p. 22ff., p. $36 \mathrm{ff.}$., p. 99ff.; Christoph Meinel, "Enzyklopädie der Welt und Verzettelung des Wissens: Aporien der Empirie bei Joachim Jungius”, in F.M. Eybl et al. (eds.), Enzyklopädien der frühen Neuzeit. Beiträge zu ihrer Erforschung (Tübingen: Max Niemeyer, 1995), pp. 162-187.

7 Cf. Markus Krajewski, Paper machines. About cards \& catalogs, 1548-1929 (Cambridge, MA: The мiт Press, 2011).

8 At the time of his death, there were an additional four freestanding cardboard card boxes filled with cards containing bibliographical information.

EBSCO : eBook Collection (EBSCOhost) - printed on 3/13/2019 4:08 AM via UNIVERSITÄT BIELEFELD AN: 1368111 ; Cevolini, Alberto.; Forgetting Machines : Knowledge Management Evolution in Early Modern Europe 
the backsides of hectographed copies, private notes, or old invoices from his father's brewery). Luhmann used these slips of paper to note the results of his reading, his own theses and concepts, as well as questions and bibliographical references. All in all, the file consists of approximately 9o,ooo index cards organized in two collections.

(a) The early collection (approximately 1951-1962), based primarily on his readings in political science, administrative studies, organization theory, philosophy, and sociology, was compiled mostly during his time as a legal trainee (Rechtsreferendar) in Lüneburg and as a senior civil servant (Oberregierungsrat) at the Ministry of Education and Cultural Affairs in Lower Saxony. The collection consists of seven drawers with approximately 23,000 cards, which are divided into 108 sections by subjects and numbered consecutively, two bibliographies comprising about 2,00o titles, and a keyword index with roughly 1,250 entries.

(b) The later collection (c. 1963-1996) covers the major part of Luhmann's publication activity and, from the beginning, clearly reflects a sociological approach. This collection is divided into eleven top-level sections that are numbered consecutively (with a total of about 100 subsections). It fills 21 drawers with approximately 67,000 cards. In addition to the notes proper, there is a sizable but obviously incomplete bibliographical apparatus with roughly 15,000 references, a keyword index with 3,200 entries, as well as a short (and incomplete) index of persons containing 300 names. ${ }^{9}$

Luhmann never explained why he started a second collection in the early 1960 s that was largely intended to replace the first one - which can be assumed from the fact that the numbering of the cards started with number one again. One can suspect that this had to do with his turn toward sociology in the early $196{ }^{10}{ }^{10}$ and his first drafts of a universalistic theory of the social, which required re-conceptualizing the structure of the collection. Accordingly, the two collections are only loosely connected, i.e., there are relatively few references between the collections where even the same (key) concepts are involved (such as role, informal organization, institution).

The bulk of the collections (approximately 75,000 cards) consists of notes documenting the results of Luhmann's readings, his own thoughts, and ideas for publication projects. To facilitate use, he generally took notes only on one side of the card. Whereas the early notes from the 1950s and 196os frequently tended to be more of the running-text kind and more closely reflected the

$9 \quad$ Below, Zettelkasten I stands for the first, Zettelkasten II stands for the second file.

10 In 1960-1961, Luhmann spent a year at the Harvard School of Public Administration in Cambridge, MA, where he attended lectures by Talcott Parsons, the leading sociologist in the field of systems theory at the time.

EBSCO : eBook Collection (EBSCOhost) - printed on 3/13/2019 4:08 AM via UNIVERSITÄT BIELEFELD AN: 1368111 ; Cevolini, Alberto.; Forgetting Machines : Knowledge Management Evolution in Early Modern Europe 
original readings, they increasingly became more compact and thesis-like in the 1970s. Particularly, these later notes were not simply excerpts. Rather, Luhmann jotted down only a few keywords in the course of his reading along with the respective page numbers, some of which he also wrote on the back of the cards containing bibliographical information in the second collection. These notes are extremely brief and are not really excerpts in the strict sense - for instance, the notes from reading an entire book frequently fit onto one of these cards, as the following ones from his reading of Friedrich Schlegel's novel Lucinde illustrate, found on the back of the card listing the book's bibliographical information (see Fig. 12.1).

Instead of giving an exact account of what he had read, Luhmann made notes on what came to his mind in the process of reading, with an eye to the notes already contained in his file. "What mattered to him was "what could be utilized in which way for the cards that had already been written. Hence, when reading, I always have the question in mind of how the books can be integrated into the filing system".12 Moreover, he never put his notes directly into the file, nor did he file them in exactly the same way that he had taken them. In a second step soon after he had completed his reading, he would prepare the notes that he had taken by organizing them according to his filing technique (see below). At this point, his main concern was not to develop an idea to maximum sophistication; rather, he operated on the assumption that a decision on the usefulness of a note could only be made in relating it to the other notes - and therefore would (in many cases) be a matter to be decided in the future. In this vein, Luhmann, in one of his notes, called his file a 'ruminant'. "All the random ideas, all the coincidental readings can be incorporated. It is then a matter of internal fit [Anschlußfähigkeit]". ${ }^{3}$ This being the case, it was not clear right from the beginning where the note to be added would be inserted into the collection - this was a decision that was made in the course of preparing the respective note for filing.

However, the collection does not reveal on first glance how the filing system functioned and how Luhmann used it in his work. What then makes this

\footnotetext{
11 Perhaps, this circumstance also explains the phenomenon familiar to many Luhmann readers that it is often difficult to find the argument in the publications by other authors that Luhmann cited them for.

12 Luhmann, "Biographie, Attitüden, Zettelkasten", p. 150. In the process, Luhmann frequently read the text from multiple perspectives, i.e., with several different questions or publication projects in mind.

13 Niklas Luhmann, Zettelkasten II, index card no. $9 / 8$ i. In the second file collection, there is a section where Luhmann filed notes about the function of his filing system. The following quotes are taken from there.
}

EBSCO : eBook Collection (EBSCOhost) - printed on 3/13/2019 4:08 AM via UNIVERSITÄT BIELEFELD AN: 1368111 ; Cevolini, Alberto.; Forgetting Machines : Knowledge Management Evolution in Early Modern Europe 
294

SCHMIDT

8 genichor de Gennsses

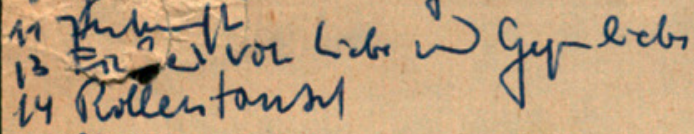

$36 \mathrm{~J} u$

42 th sluatiben: Galmerir

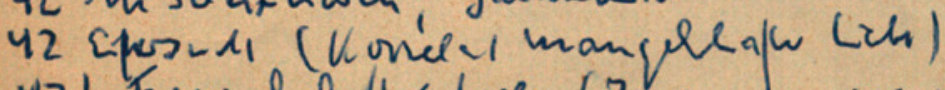

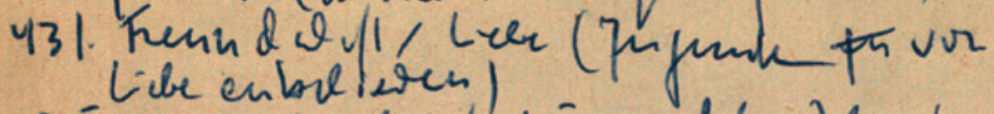

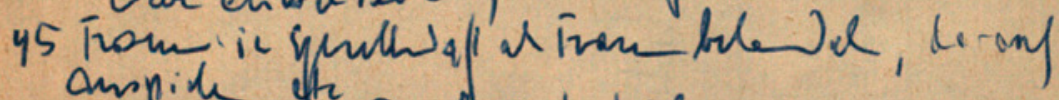
ampich tete Einds) iv Lich

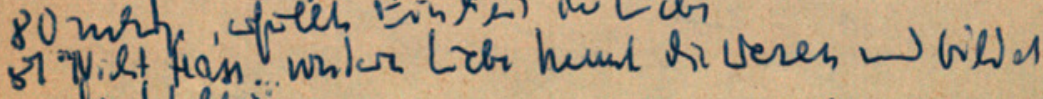

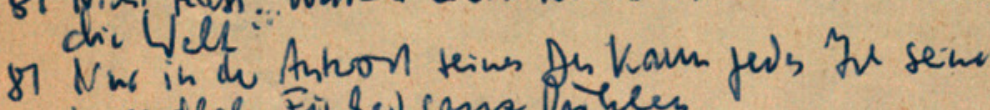
unenders Einhel sanz pheen.

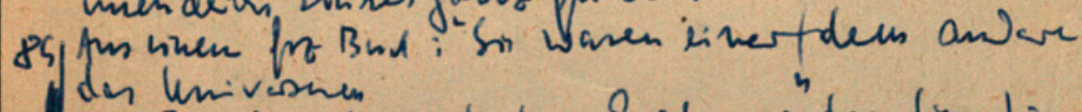

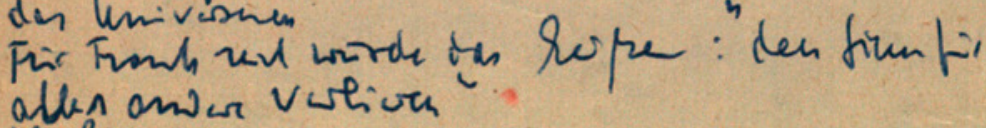

Nihl so viv

45 1. Nuflestion: Berng any huberim th 47 Hwowr - in Risen Kortesl

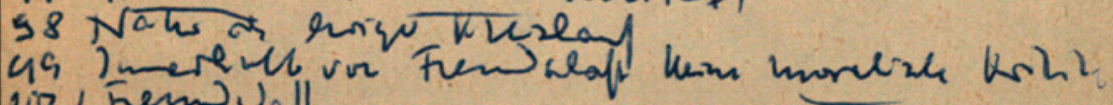
$102 /$ Fermuoll




MBli Dasiles a Thure os Roman in Roun.

FIGURE 12.1 Niklas Luhmann's excerpt of Friedrich Schlegel's Lucinde (1799)

(C) THIS IMAGE IS REPRODUCED BY PERMISSION OF THE BIELEFELD UNIVERSITY.

EBSCO : eBook Collection (EBSCOhost) - printed on 3/13/2019 4:08 AM via UNIVERSITÄT BIELEFELD

AN: 1368111 ; Cevolini, Alberto.; Forgetting Machines : Knowledge Management Evolution in Early Modern Europe

Account: bielefeld.main.ehost 
notation system so special that Luhmann ${ }^{14}$ called it his 'secondary memory'? The most important aspect of this external memory device was not that these written notes were supposed to support Luhmann's own memory. The main issue was rather that the file could enter into an exchange with Luhmann's 'primary memory' - this is at least how Luhmann described his relationship to his file. He perceived it as being a partner in a communication process in which the participants remain black boxes for one another. ${ }^{15}$ The index card file and its user could enter a productive relationship because the internal structure of the file collection turned it into an innovative mechanism that, although requiring the user to ask questions, gave responses that surprised the asking person, even if that person was the author of cards. "Without those cards, just by contemplating, these ideas would have never occurred to me. Of course, my mind is needed to note down the ideas, but they cannot be attributed to it alone", said Luhmann. ${ }^{16}$ The file is thus a surprise generator. But how is it possible that the filing system could develop a creativity of its own; that is to say, how could it systematically lead to ideas that do not lie at hand?

Luhmann's answer was that one must teach one's communication partner to achieve autonomy: to develop its own mode of creating and reducing complexity. This is accomplished by combining a specific system of organization and method of card integration with specific rules of numbering, an internal system of references, and a comprehensive keyword index.

\subsubsection{System of Organization and Method of Card Integration}

In talking about his index card file, Luhmann repeatedly highlighted its unique structure, which he claimed to explain its productivity as a 'text generator'. According to him, the file was a 'cybernetic system', a "combination of disorder and order, of clustering and unpredictable combinations emerging from ad hoc selection". ${ }^{17}$

Yet, even though the file does not feature a systematic classification system and order of contents, it is not simply a chaotic compilation of notes but an aggregation of a vast number of cards on specific concepts and topics. Both collections are characterized, accordingly, by providing a rough structure by subject areas, which is also reflected in the first number assigned to the card

14 Niklas Luhmann, "Kommunikation mit Zettelkästen. Ein Erfahrungsbericht", in H. Baier et al. (eds.), Öffentliche Meinung und sozialer Wandel: Für Elisabeth Noelle-Neumann (Opladen: Westdeutscher Verlag, 1981), pp. 222-228, at p. 225.

15 Luhmann, “Kommunikation mit Zettelkästen”, p. 222f.

16 Luhmann, “Biographie, Attitüden, Zettelkasten”, p. 144.

17 Luhmann, Zettelkasten II, index card no. $9 / 8$.

EBSCO : eBook Collection (EBSCOhost) - printed on 3/13/2019 4:08 AM via UNIVERSITÄT BIELEFELD AN: 1368111 ; Cevolini, Alberto.; Forgetting Machines : Knowledge Management Evolution in Early Modern Europe 
per this system of organization followed by a comma (first collection) or slash (second collection) that separates it from the rest of the number given each card. However, both collections clearly differ in terms of their primary sorting by subject areas and, consequently, in terms of their internal organization.

The first collection, dating back to the 1950s, features a fairly large number of sections differentiated by subject areas -108 , specifically. The pattern that we see here is very much one of exploring and reflecting on largely predetermined, fairly detailed fields of knowledge such as state, equality, planning, power, constitution, revolution, hierarchy, science, role, concept of world, information, and so on. The categories are still itemized in a way that more resembles a list (albeit already largely of an unsystematic nature), which was then worked through in detail, item by item. If one were to classify this collection by disciplines, it would fall into the fields of jurisprudence, political science, administrative studies, and philosophy, whereas sociology still plays an only marginal role, even though the collection already contains a fairly large section on functionalism.

The second collection, by design, is more problem-oriented and clearly more centred on sociology. It also differs considerably from the first collection in terms of its structure. There remain only eleven top-level subject areas: organizational theory, functionalism, decision theory, office, formal/informal order, sovereignty/state, individual concepts/individual problems, economy, ad hoc notes, archaic societies, advanced civilizations. What this compilation immediately illustrates is that it is not simply a list or a system of order in the sense of a taxonomy or a book's table of contents. Rather, the collection's first level of organization is clearly the historical product of Luhmann's reading and research interests. His work during the 1960s was characterized by his interest in the concept of function as well as in issues of organizational sociology arising in the context of his preoccupation with administrative organization. He began with an assessment of previous approaches to understanding organizations, which led him to the model of functional analysis and to the concept of decision-making as an alternative to these approaches. In light of empirical studies on administrative organization, the concept of office played an important role, and the distinction between formal and informal order, among others, provided a means of getting a genuinely sociological grip on the subject matter. ${ }^{18}$

18 This is not to say that the sections mentioned above were filled in linear fashion, one after another. In accordance with his specific mode of integrating cards into the file (see below), he would continuously add new cards in an ongoing process. For the sections that he added later, there is no discernible systematic connection to the conceptual design of the first sections. Whereas the section on economy originated in the process of preparing

EBSCO : eBook Collection (EBSCOhost) - printed on 3/13/2019 4:08 AM via UNIVERSITÄT BIELEFELD AN: 1368111 ; Cevolini, Alberto.; Forgetting Machines : Knowledge Management Evolution in Early Modern Europe 
Following the subject areas defined at the top level by the eleven sections mentioned above are other subsections that revolve around a variety of topics and are at least loosely connected with the main topic. Each of these subsections was assigned a numerical prefix of up to four digits. The relation between top-level subject area and the lower-level subjects cannot be described in terms of a strictly hierarchical relationship, as the following list from the third section illustrates:

\section{Zettelkasten II - Structural Outline: 3 General Decision Theory ${ }^{19}$}

\section{General decision theory}

31 Concept of action

32 Models of decision-making

33 Types of decision-making model designs

331 Utilitarian models

332 Optimizing model

333 Satisfying model (theory of acceptable decisions)

34 Simplification of decision-making

341 Anticipatory simplification

3411 Ideology

3412 Authority (organization)

3413 Rules

3414 Legal system

3415 Unplanned structures in the field of decision-making

342 Techniques of decision-making

35 Organization of decision-making

the manuscript for his book on the economic system in the 1980s - cf. Niklas Luhmann, Die Wirtschaft der Gesellschaft (Frankfurt am Main: Suhrkamp, 1988) - and, in this respect, broke with his usual method, the sections devoted to individual concepts/individual problems and ad hoc notes appear to be organized according to principles reflecting the garbage-can model, according to which notes on seemingly random, unrelated topics of various kinds were filed consecutively. Section 7 , for instance, on individual concepts/ individual problems features 120 subsections with contents that have no inherent relation to one another and which often contain only a few cards but in some cases also extensive notes as in the category of truth/science (which he probably compiled while preparing the book on the system of science). Cf. Niklas Luhmann, Die Wissenschaft der Gesellschaft (Frankfurt am Main: Suhrkamp, 1990).

All terms are the author's translations from the German.

EBSCO : eBook Collection (EBSCOhost) - printed on 3/13/2019 4:08 AM via UNIVERSITÄT BIELEFELD AN: 1368111 ; Cevolini, Alberto.; Forgetting Machines : Knowledge Management Evolution in Early Modern 
A specific system of organization applied within these sections on a particular subject matter ensured that the initial decision for a specific topic did not lead to a sequence of cards confined to that one topic. Whenever Luhmann came across an interesting idea about a secondary aspect on one of his cards, he pursued this idea by adding additional notes and inserted the respective card at that place in the existing sequence of cards. This method could be applied again to the card that had been inserted, the result being a sequence of cards leading farther and farther away from the initial subject, which enabled the collection to grow 'inwardly'. For instance, when we look up the keyword 'functionalism', we find the following sequence of terms: concept of function unit of reference of functional analysis - concept of conditions for continued existence - concept of functional problem - concept of expectations - social identity - sincerity - secret. $^{20}$

The positioning of larger subject areas as well as individual cards in the collection was not simply the historical product of Luhmann's reading interests and note-taking activities. It also owed to the difficulty of assigning an issue to one and only one single (top-level) subject. Luhmann solved this problem by seizing it as an opportunity: instead of subscribing to the idea of a systematic classification system, he opted for organizing entries based on the principle that they must have only some relation to the previous entry without also having to keep some overarching system in mind. To illustrate this, we find, for instance, extensive notes on economic issues such as money and property not only in the aforementioned larger section on economy but also in Section 3 ('decision theory'), subsection $35^{2}$ ('communication theory'), whereas we encounter the notes on the functional subsystem of 'law' that are the equivalent to those on economy not in a top-level section of their own but in Section 3 ('decision theory'), subsection 34 ('concept of decision-making'), and the notes on 'science' mostly in Section $7 / 25$ ('truth'), which are part of Section 7 ('individual concepts/individual problems'). ${ }^{21}$

This indicates, accordingly, that the positioning of a subject within this system of organization reveals nothing about its theoretical importance for there exist no privileged positions in this web of notes. ${ }^{22}$ Consider, for instance, the cards on autopoiesis, which is one of the key concepts in Luhmann's more recent social theory. Most of these cards in the second collection are filed under what seems to be a subordinate position in this system bearing

\footnotetext{
20 All terms are the author's translations from the German.

21 All terms are the author's translations from the German.

22 Luhmann, “Kommunikation mit Zettelkästen”, p. 225.
} 
the number $21 / 3 \mathrm{~d} 26 \mathrm{gii}$. The same is true for his notes on his major project of a theory of society, which are located in the same subsection under the number $21 / 3 \mathrm{~d} 27 \mathrm{fB}$.

Positioning of Subjects and Theoretical Importance ${ }^{23}$

21 Concept of function

21/3 Unit of reference in functional analysis

21/3d Concept of system (clarification of the concept of system)

21/3dı Concept of system - concept of continued existence (relative invariance)

21/3d 5 Parsons' systems theory

21/3d 7 Systems/environment theory (system - environment relations)

21/3d18 System/world

21/3d18d Meaning

21/3d19 System boundaries

21/3d2o Simple/complex systems

21/3d 26 Function of system formation

$21 / 3 \mathrm{~d} 26 \mathrm{~g}_{1}$ Systems-theoretical concept of reflection

21/3d26gii Autopoiesis

21/3 $\mathrm{d} 27 \mathrm{f}$ Application areas of the theory of social systems

$21 / 3 \mathrm{~d} 27 \mathrm{fA}$ Theory of organized social systems

21/3d27fB Theory of society

21/4 Functional/dysfunctional

The decision inherent in this filing technique to do without a fixed system of order is an essential prerequisite of the creativity of Luhmann's filing system. In explaining his approach, he not only underlined the fact that he saw no problems in handling his file in this way but, with computer technology in mind, also emphasized the benefits of the principle of 'multiple storage'.24 Applied to the filing system, the latter serves to provide different avenues of accessing a topic or concept since the respective notes may be filed in different places and different contexts. Conversely, embedding a topic in various contexts gives rise to different lines of information by means of opening up different realms of comparison in each case.

\footnotetext{
23 All terms are the author's translations from the German.

24 Luhmann, Zettelkasten II, index card no. 9/8b2.
}

EBSCO : eBook Collection (EBSCOhost) - printed on 3/13/2019 4:08 AM via UNIVERSITÄT BIELEFELD AN: 1368111 ; Cevolini, Alberto.; Forgetting Machines : Knowledge Management Evolution in Early Modern Europe 
At first glance, Luhmann's organization of his collection appears to lack any clear order; it even seems chaotic. However, this was a deliberate choice. It was Luhmann's intention to "avoid premature systematization and closure and maintain openness toward the future". ${ }^{25} \mathrm{~A}$ prerequisite for a creative filing system, Luhmann noted, is "avoiding a fixed system of order". ${ }^{26} \mathrm{He}$ pinpoints the disadvantages that come with one of the common systems of organizing content in the following words: "Defining a system of contents (resembling a book's table of contents) would imply committing to a specific sequence once and for all (for decades to come!)". ${ }^{27}$ His way of organizing the collection, by contrast, allows for it to continuously adapt to the evolution of his thinking.

However, the history of choices made as the collection evolved is also clearly reflected in the significant differences in the density of the notes added at later points in time. Whereas a steady stream of added notes resulted in an unfettered inward growth of some areas over time, one repeatedly encounters entire sets of cards - particularly from the 1960 os in the context of his reflections on issues in administrative and organizational sociology - that were not only written as running text in a more linear fashion but were also only rarely added onto by inserting new cards later on. In these cases, we might even speak of 'black holes', that is, of parts of the file that seem to have sunk into oblivion as he did not add onto them anymore. In Luhmann's own words: "Some things fade away; some notes are never seen again. On the other hand, there are preferred foci, clusters, and regions where you work more frequently than in other areas. There are sets of ideas that were anticipated to become major complexes and are never elaborated; and there are secondary ideas that came to mind that gradually become more enriched and inflated; that are initially positioned so as to play a minor role in a text and then increasingly come to dominate the system". 28

\subsubsection{System of Numbering}

Getting the filing system 'to speak', if you will, requires an additional prerequisite: the possibility of addressing each card individually and hence also of finding it again. Thus, the filing technique outlined above does not build on the idea of a order of contents but of a fixed order of positioning. This idea is at the root of Luhmann's specific notational system. Each card is assigned a

\footnotetext{
25 Luhmann, Zettelkasten $I I$, index card no. $9 / 8 \mathrm{~h}$.

26 Luhmann, Zettelkasten II, index card no. $9 / 8$.

27 Luhmann, "Kommunikation mit Zettelkästen", p. 224.

28 Luhmann, “Kommunikation mit Zettelkästen", p. 225.
} 
number ${ }^{29}$ and, thus, a fixed position in the file that does not change over time: card 1,1 (or 1/1, as the case may be) is followed by 1,2 (or 1/2), and so on; a card that was created later and pursues an aspect further that is noted on card 1,1 was given the number 1,1a and inserted between card 1,1 and 1,2; at that point, either a card 1,1b on that very same topic could be added or another card 1,1a1 breaking things down further or pursuing other aspects, which would then be inserted between 1,1a and 1,1b, and so forth.

\title{
Illustration of the Method of Card Integration and Numbering ${ }^{30}$
}

\author{
1/1 Card with notes \\ 1/1a Card containing notes referring to a concept/idea from card $1 / 1$ \\ $1 / 1 b$ Continuation of notes from card $1 / 1 a$ \\ $1 / 1$ b Card containing notes referring to a concept/idea from card $1 / 1 b$ \\ $1 / 1 b_{2}$ Continuation of notes from card $1 / 1 b_{1}$ \\ $1 / 2$ Continuation of notes from card $1 / 1$
}

In conjunction with the method of card integration outlined above, this numbering system results in cards that bear a combination of numbers and letters with up to 13 digits (e.g., 21/3a1p5c4fBia Confidentiality); in some cases, we also find several 100 cards that were later inserted between what had initially been two consecutive cards created at the same time on a related subject. The file collection thus features a unique depth in its mode of organization that Luhmann referred to as a "capacity for internal ramifications" (innere Verzweigungsfähigkeit). ${ }^{31}$

\subsubsection{System of References}

In addition to Luhmann's notation and numbering system, there is another key feature of the collections that accounts for the creativity of this filing system, namely, a system of referencing in which Luhmann noted a card number on one or several other cards. An estimate based on a sample count suggests that

29 Although they bear a number, the card entries are not dated. The only way to determine their approximate time of creation in retrospect is via the literature cited and changes in Luhmann's handwriting over the years.

30 For reasons of clarity, the principle of numbering that Luhmann applied will be illustrated in simplified fashion. In addition to the sequence outlined below, there are also cards that are numbered using two consecutive numbers or letters (e.g., 1/1aa or $1 / 2,1$ ). This pattern is a consequence of applying the described method of adding cards and inserting a card in an already existing sequence at a later point in time. 


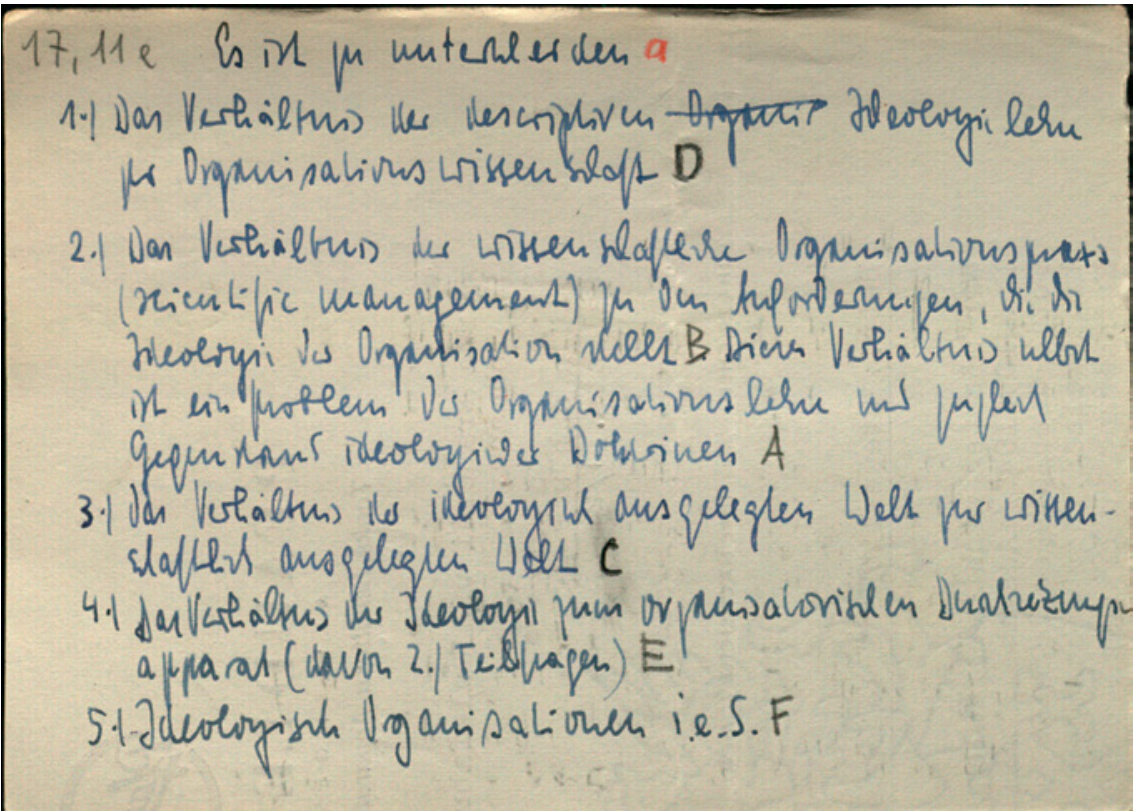

FIGURE 12.2 Niklas Luhmann, Zettelkasten I, index card no. 17,11e

the first collection contains approximately 20,000 references and the second about 25,000-30,000 references of this kind, with remarkably few references between the two collections.

We can distinguish three types of references:

(a) references in the context of a larger structural outline. Here, Luhmann, when beginning a major line of thought, noted on a card several of the aspects to be addressed and marked them by a capital letter that referred to a card (or set of consecutive cards) that was numbered accordingly and placed at least in relative proximity to the card containing the outline. This structure comes closest to resembling the outline of an article or the table of contents of a book (see Fig. 12.2).

(b) Collective references. At the beginning of a section devoted to a specific subject area, we often find a card that refers to a number of other cards in the collection that have some connection with the subject or concept addressed in that section. A card of this kind can list up to 25 references and will typically specify the respective subject or concept in addition to the number. These references can indicate cards that are related by subject matter and in close proximity or to cards that are far apart in other sections of the collection (see Fig. 12.3). 


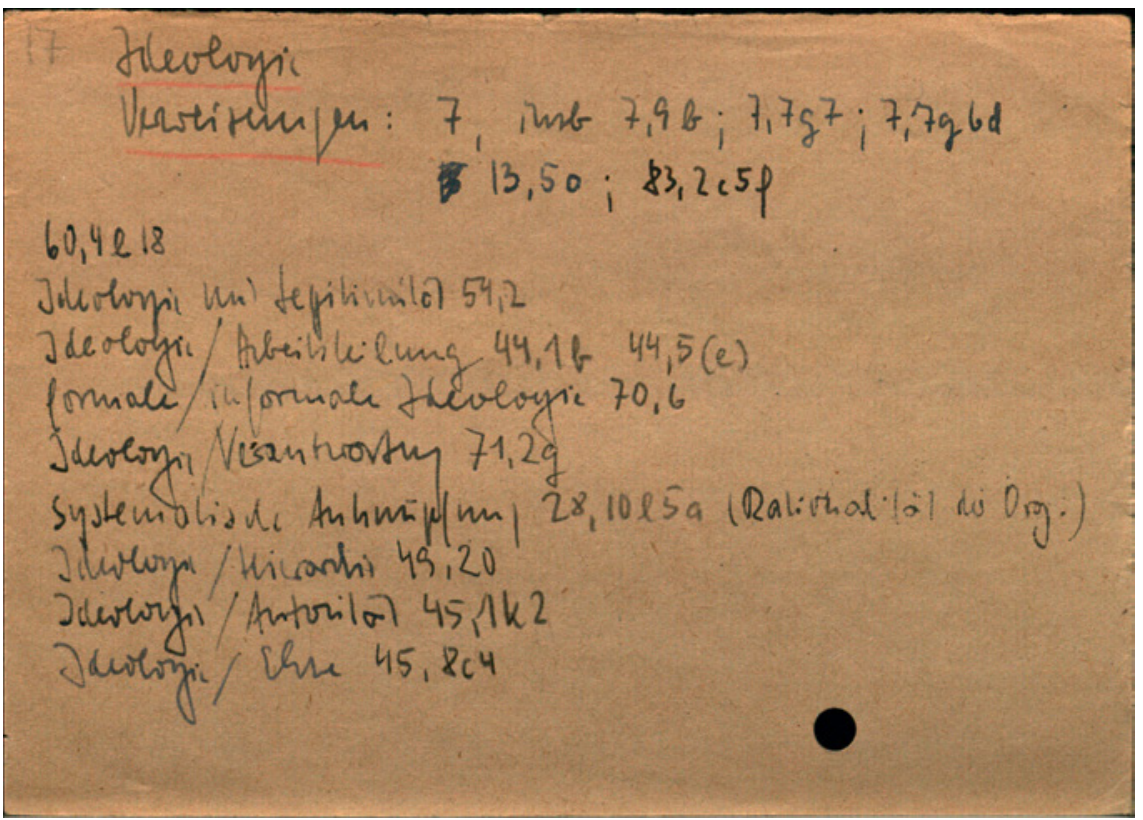

FIGURE 12.3 Niklas Luhmann, Zettelkasten I, index card no. 17

(C) THIS IMAGE IS REPRODUCED BY PERMISSION OF THE BIELEFELD UNIVERSITY.

(c) Single references. In his notes, Luhmann often made a reference to another card in the collection that was also relevant to the subject. He did this in two ways:

(c1) by adding notes containing references to a secondary aspect or idea (or several such aspects or ideas) according to the method described above; these cards were usually inserted in immediate proximity to the reference card. Contrary to his usual method, this reference does not consist of the actual card number but rather of a number written in red (beginning with 1 and ascending if the card contains several references to subsequent cards) or of a lowercase letter (starting with a), which would also be added to the actual card number on the card referred to (see Fig. 12.4 and Fig. 12.5).

(c2) By adding references relating to another index card of interest to the subject/concept in question that could be located at an entirely different place in the file, frequently in the context of a completely different discussion. This reference would involve noting the respective card number.

Luhmann noted the references directly as he created the card but also regularly updated already existing cards by adding references whenever the integration of new cards in other parts of the collection made it necessary. 
to fituarious bepenf latur sil an berren

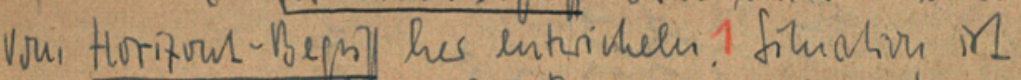

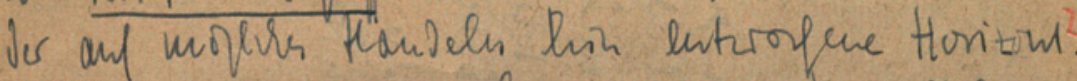

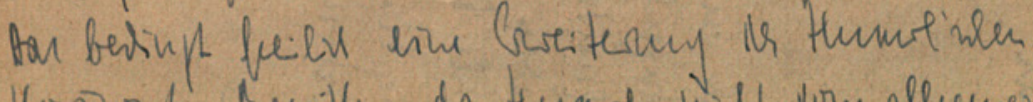

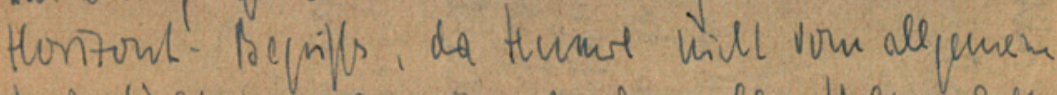

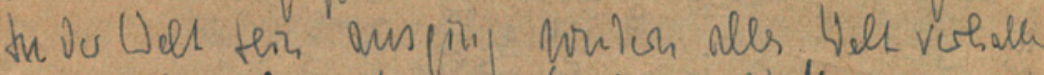

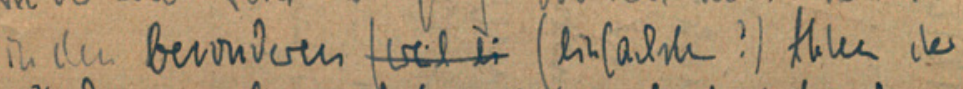

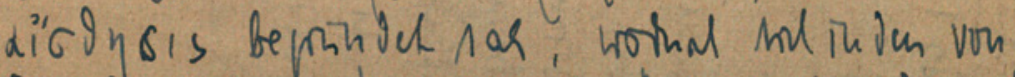

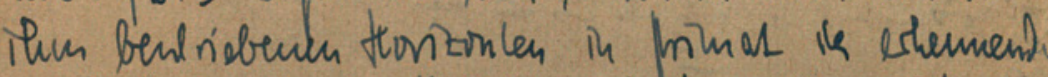

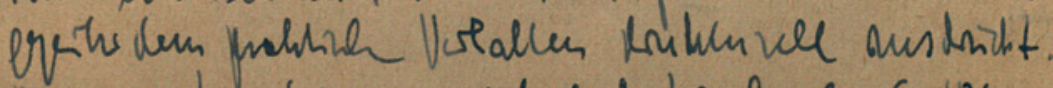
Oon, in a horrificen. - vf. and Lomiquer S. 106 Ge. K. klie S. 66l. vgl.7izea

FIGURE 12.4 Niklas Luhmann, Zettelkasten I, index card no. 17,169

$17,169,2$ So and Lang prebe in Sympl los oplein 5. 278

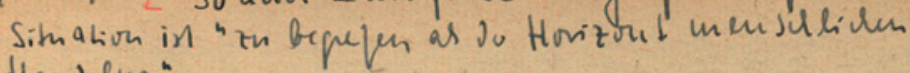
Hanielus"





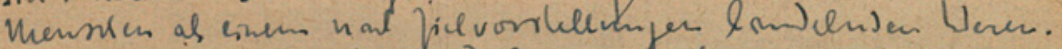

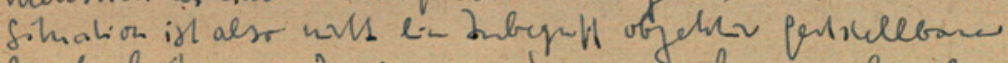

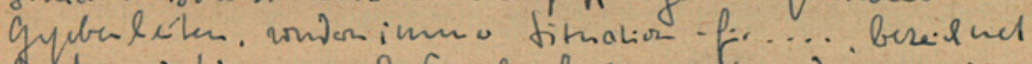

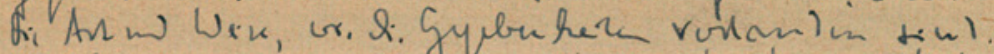



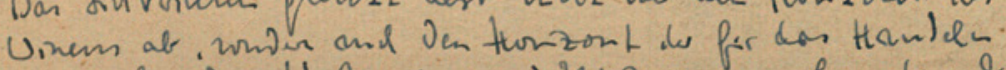

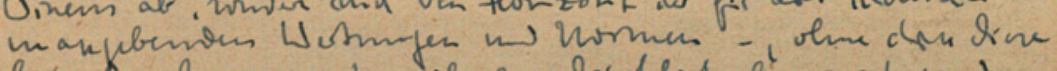

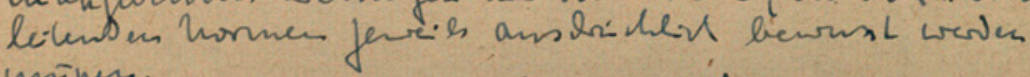
minner.

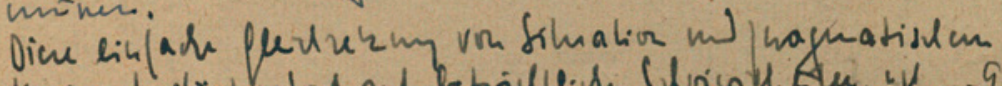

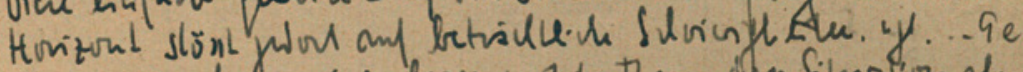

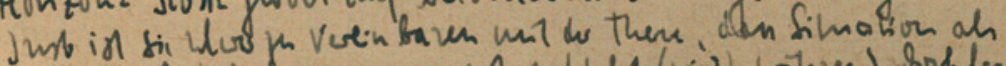

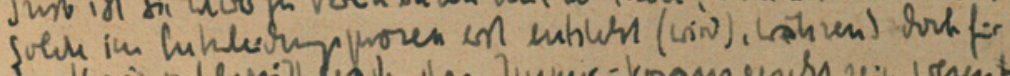

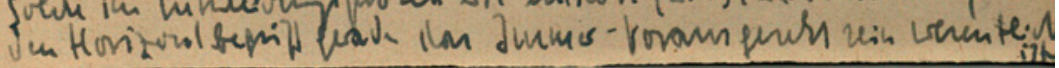

FIGURE 12.5 Niklas Luhmann, Zettelkasten I, index card no. 17,169,2 (C) THESE IMAGES ARE REPRODUCED BY PERMISSION OF THE BIELEFELD UNIVERSITY.

EBSCO : eBook Collection (EBSCOhost) - printed on 3/13/2019 4:08 AM via UNIVERSITÄT BIELEFELD AN: 1368111 ; Cevolini, Alberto.; Forgetting Machines : Knowledge Management Evolution in Early Modern Europe 
In this way, he engaged in an ongoing process of tending to his file, which explains why the file, according to him, preoccupied so much of his time and also illustrates how well he really knew it. ${ }^{32}$

Luhmann himself called his system of references a "web-like system" (spinnenartiges System). ${ }^{33}$ This metaphor suggests interpreting it along network-theoretical lines. ${ }^{34} \mathrm{~A}$ key feature explaining the productivity of this filing system is its potential for enabling 'short cuts', i.e., the fact that a reference may lead to a completely different (both in terms of subject and location), distant region in the network (file). Luhmann himself considered this feature, which counteracted the collection's primary system of organization, to be of crucial significance: "The references must not capture collective concepts that aggregate key aspects but must selectively lead away from the material subsumed under them" ${ }^{\prime 35}$ so that they facilitate interpretations and contextualizations of his notes that differed from those intended when creating and initially integrating the notes in the file system.

The cards containing a collection of references are furthermore of interest because they represent so-called 'hubs', i.e., cards that function as nodes that feature an above-average number of links to other cards so that these few cards provide access points to extensive parts of the file.

Generally speaking, Luhmann's mode of referencing outlined above made use of what would later become the common technology of 'hyperlinks' (or 'hypertext') in the computer age, although the file's analog design limited the possibilities of realizing this for technical reasons since it required the more time-consuming process of physically looking up and taking the respective card instead of a simple mouse click. ${ }^{36}$

The significance of his system of referencing cannot be overestimated in light of the described method of integrating new notes into the file and the absence of order or, put positively, openness toward the future that this mode of organizing the collection involves. "The decision where to place what in the file can involve a great deal of randomness as long as I add references linking the other options" ${ }^{37}$ Yet, this method is also fraught with certain risks,

32 Accordingly, Luhmann never created a detailed table of contents for the two collections. Only for the first collection did he make a list of its 108 sections, yet without further differentiating it. A preliminary subject overview in the context of the aforementioned project of making Luhmann's work accessible for research comprises a total of roughly 100 pages.

33 Luhmann, "Biographie, Attitüden, Zettelkasten", p. 143.

34 For a network model of this kind, see Duncan Watts, "The 'new' science of networks", Annual Review of Sociology, 30 (2004), pp. 243-270.

35 Luhmann, Zettelkasten II, index card no. $9 / 8$ bi.

$3^{6}$ See also Markus Krajewski's essay in this volume.

37 Luhmann, "Biographie, Attitüden, Zettelkasten", p. 143.

EBSCO : eBook Collection (EBSCOhost) - printed on 3/13/2019 4:08 AM via UNIVERSITÄT BIELEFELD AN: 1368111 ; Cevolini, Alberto.; Forgetting Machines : Knowledge Management Evolution in Early Modern Europe 
as Luhmann himself pointed out: "Each note is only an element that derives its quality from the web of references and cross references within the system. A note that is not linked to this web becomes lost in the file; the file forgets it". 38 This applies to individual cards as well as smaller sections since the references, although usually addressing individual cards, frequently only mark the beginning of a series of notes on a certain subject and, thus, the point of entry into a subject area. Accordingly, we repeatedly find sets of cards that have not, or rarely, been revisited since the time they had been created, which can be inferred from their condition and the fact that no later notes were added and no other cards refer to them. Here, too, the inherent momentum of black holes applies: parts of the file that are poorly linked, or not linked at all, with other parts tend to remain isolated later on. Of course, in many cases this quasiinstitutionalized oblivion was founded on reasons relating to Luhmann's research, as they represented conceptual lines of thought that Luhmann no longer pursued for theoretical reasons.

\subsubsection{Keyword Index}

The structure of the file described so far ultimately provides the backdrop to understanding the function of the keyword index. The absence of a fixed system of order and, in consequence, a table of contents turned the index into the key tool for using the file - how else should one be able to find certain notes again and thus gain access to the system of references? Not wanting to rely on pure chance requires being able to identify at least one point from which the respective web of references can be accessed. This is the purpose of the keyword index. ${ }^{39}$

Whereas the index to the first collection was still of fairly manageable size with its 1,250 entries, the continuous updates of the index to the second collection ${ }^{40}$ ultimately resulted in 3,200 entries. Contrary to the subject index of

38 Luhmann, “Kommunikation mit Zettelkästen", p. 225.

39 The collection also features an index of persons - although of a very rudimentary nature - consisting of 300 entries. The idea behind this index presumably was to be able to access the collection via names as well. In the bibliography - which is also incomplete and contains approximately 2,000 titles in the first and some 15,000 titles in the second collection - we also occasionally find the numbers of the cards on which Luhmann documented the results of his readings, so that the collections could be accessed via persons as well as works (see Luhmann, “Kommunikation mit Zettelkästen”, p. 225). However, Luhmann did not systematically pursue this strategy.

40 The second collection contains four versions of the keyword index. Each time the process of continuously adding onto the index resulted in its alphabetical order becoming messy, Luhmann created an entirely new version of the index.

EBSCO : eBook Collection (EBSCOhost) - printed on 3/13/2019 4:08 AM via UNIVERSITÄT BIELEFELD AN: 1368111 ; Cevolini, Alberto.; Forgetting Machines : Knowledge Management Evolution in Early Modern Europe 
a book, the file's keyword index makes no claim to providing a complete list of all entries in the collection that refer to a specific term. Rather, Luhmann typically listed only one to three places where the term could be found in the file, the idea being that all other relevant entries in the collection could be quickly identified via the internal system of references. By contrast, the large number of keywords listed in the keyword index indicates that this index was at least intended to meet the standard of completeness.

The principles according to which the collections are organized have as a consequence that accessing the file via the keyword index exactly does not limit the search to that term only. Quite to the contrary, the specific method of integrating cards and his system of referencing ensure that any search soon opens up a vast web of notes. This can be illustrated by looking at a selection of cards on the concept of risk as an example. In the keyword index, we find a total of five entries with six references to the conceptual complex of 'risk' (see Fig. 12.6).

For the general concept of risk (Risiko, Riskanz allg.), there is a reference to a section starting with the number 21/3d18c6oog ('transformation of risk'), which is part of a larger section on the concept of system in the second collection

$\mathrm{Rh}-\mathrm{Ri}$

Ritualismus in Organisationen $532 / 5 c 7 a ; 44 / 12 \mathrm{~d} 3$

Richterrecht $3414 / 11 \mathrm{~b} 3$

Rhetorik 21/3alp5, 1 21/3alpe9pa 7/25g17d7 7/9d

Richtpunkte $532 / 4 \mathrm{~b} 6,6 \mathrm{e}$

-Risikobewußtsein und Bereitschaft 333/10el9d

-Ritus 21/3alp4/A19; 34/4d

Risiko (Medien) 32/3gl3n; 7/25a30

rites de passage $3411 / 18 \mathrm{fl} 14 \mathrm{~b}$

Risiko, evolutionär $54 / 14$ s

Rigidität $7 / 52$

Ritual (religiös) 3411/18m6b

Risiko, Entscheidung als 3/10d

Risiko, Riskanz allg. 21/3d18c6009

Richtigkeit $32 / 3 a 9 ; 7 / 25 f l h l 8$

Rhythmos $3411 / 18 \mathrm{q} 3 \mathrm{c} 52 / 25 \mathrm{k}$

FIGURE 12.6 Niklas Luhmann, Zettelkasten II, Keyword index card Rh-Ri

(C) THIS IMAGE IS REPRODUCED BY PERMISSION OF THE BIELEFELD

UNIVERSITY.

EBSCO : eBook Collection (EBSCOhost) - printed on 3/13/2019 4:08 AM via UNIVERSITÄT BIELEFELD

AN: 1368111 ; Cevolini, Alberto.; Forgetting Machines : Knowledge Management Evolution in Early Modern Europe

Account: bielefeld.main.ehost 
and, more specifically, part of the section on the theorem of the reduction of complexity. There, we encounter another set of references to subjects along various other lines and in very different parts of the file (e.g., on security, decision, evolution, media, uncertainty, legislation/science, participation, economy, death). When we follow the first reference to section 'security' $(7 / 28)$, the first card $(7 / 28,1)$ immediately refers us to cards on related topics, among them the subjects 'absorption of risk' (34/4), 'safety/work atmosphere' (532/5d3j2b), 'legal certainty' (3414/27), and 'certainty/truth/science' ( $7 / 25 \mathrm{~b} 30 \mathrm{k})$. The very first reference on the card $7 / 28,1$ leads to Section $21 / 802$ on structural issues concerning the significance of security for the reduction of uncertainty in the context of information theory. Here, again, we quickly $(21 / 802,2)$ encounter another reference to, among other things, an entire section on the 'absorption of uncertainty' (34/4) - where there immediately are references to other sections such as 'responsibility' (333/10e), 'uncertainty as an information variable' $(44 / 2 \mathrm{~d} 5)$, 'money/power as absorption of uncertainty' (352/16a6), 'liquidity' (532/4a5farza), as well as the 'process of education' ( $7 / 25958)$.

Paths of References Using the Example of 'Risk, riskiness, general' $(21 / 3 \mathrm{~d} 18 \mathrm{c} 600 \mathrm{~g})^{41}$

21/3d18c6oog Transformation of risk, riskiness

$\rightarrow$ Safety/security $7 / 28$

$\rightarrow$ Absorption of uncertainty $34 / 4$

-> Responsibility 333/10e

$\rightarrow$ Uncertainty as an information variable $44 / 2 \mathrm{~d}_{5}$

-> Money/power as absorption of uncertainty 352/16a6

$\rightarrow$ Liquidity 532/4a5farza

-> Process of education $7 / 25958$

$\rightarrow$ Safety/work atmosphere $532 / 5 \mathrm{~d} 3 \mathrm{j} 2 \mathrm{~b}$

-> Legal certainty $3414 / 27$

$\rightarrow$ Certainty/truth/science $7 / 25 \mathrm{~b} 3 \mathrm{ok}$

-> Uncertainty $21 / 3 \mathrm{~d} 25$

$\rightarrow$ Legislation/science $3414 / 14 \mathrm{p}$

$\rightarrow$ Economy 8/40

$\rightarrow$ Death as a risk $7 / 81$

41 The path illustrated here is only the first one resulting from the first reference on each card. Moreover, I have not listed all references but only those that lead to more distant parts of the collection (author's translation from the German).

EBSCO : eBook Collection (EBSCOhost) - printed on 3/13/2019 4:08 AM via UNIVERSITÄT BIELEFELD 
This example demonstrates how quickly this technique of referencing leads away from the original topic to a variety of other subjects that the user initially would not have associated with the first one; it also shows how potential relationships between these topics may not have come to mind in the absence of such a chain of references. Thus, a query via the keyword index in combination with this system of references systematically brings chance into play and creates connections among a variety of heterogeneous aspects - although in a theoretically and conceptually controlled manner. ${ }^{42}$

\subsubsection{Summary}

It is specifically not (only) the paths that Luhmann tread in his initial readings and note-taking that are constitutive of his filing system but rather the special filing technique and the (selective) relations established between his notes by means of his referencing technique that make it possible to retrieve more in a later query via the pivotal keyword index than what was intended when the notes were initially taken. As early as in the 1950s-196os, Luhmann simulated a modern computer-based database system by applying the multiple-storage principle in filing subjects and utilizing his referencing technique, by which he anticipated what would become the common technology of hyperlinking in the era of the World Wide Web. The file's analog design, however, limited the realization of its potential for technical reasons since it required the more time-consuming process of physically looking up and taking out the respective card instead of a simple mouse click.

We must also not lose sight of the fact that Luhmann's filing system, apart from its surprise-generating function, rooted in its structure of organization, also - and above all - served him as a thinking tool. This is not only true in terms of the proposition that the file acted as a communication partner in the research process but also in regard to the fact that in Luhmann's mind the process of writing things down enables disciplined thinking in the first place: "Underlying the filing technique is the experience that without writing, there is no thinking". ${ }^{43}$ Accordingly, the file also documents the evolution of important theoretical constructs in Luhmann's thinking: for instance, the concepts of communication media, evolution, or observation. It contains not only validated knowledge but also reflects the thought process, including potential mistakes and blind alleys that were later revised but not removed from the file as the original cards always remained in Luhmann's file and perhaps a new card with revisions was added if needed. In this sense, the file is more than

\footnotetext{
42 See Luhmann, “Kommunikation mit Zettelkästen", p. 226.

43 Luhmann, Zettelkasten II, index card no. 9/8g.
}

EBSCO : eBook Collection (EBSCOhost) - printed on 3/13/2019 4:08 AM via UNIVERSITÄT BIELEFELD AN: 1368111 ; Cevolini, Alberto.; Forgetting Machines : Knowledge Management Evolution in Early Modern Europe 
just an analog database of Luhmann's theory: it can be seen as - drawing on the words of Erving Goffman ${ }^{44}$ - the backstage of his theory and therefore as Niklas Luhmann's intellectual autobiography.

\subsection{The Relation between Filing System and Publications}

How must we conceive of the relation between Luhmann's index card and his publications against this backdrop? Using the example of his presentation on How can modern society adapt to ecological endangerment? ${ }^{35}$ Luhmann described the process of drawing on his file to compose texts as a kind of collaging technique in which he combined the various sections on issues that are relevant to a topic. ${ }^{46} \mathrm{He}$ explained that producing this text required (no more than) combining the entries on the concept of functional differentiation, self-referential systems, and binarity (leaving the question open, however, of whether this idea of relating parts to one another in this way might be a product of the interaction between file and author to begin with). However, comparing the pertinent sections of the file, some of which are quite extensive, with the article in question quickly reveals that the 14-page presentation - as could be expected - comes nowhere near to reflecting the complexity that the file weaves around these issues. The presentation makes only a few brief remarks on functional differentiation; and even in this case, the section in the file contains several cards that were obviously produced only at the time of preparing the presentation. ${ }^{47}$

This interaction between publications and filing system not only suggests that it is not the latter alone that constitutes the cybernetic system but first and foremost the relation between the filing system and the publications to which it gave rise since the file, at least in the more mature stage of Luhmann's theory-building since the 1970s, did not serve as a pure archive that he would develop independent of specific publication projects (of which there were always some ongoing). Rather, the file would be filled as he responded to publication

44 Erving Goffman, The presentation of self in everyday life (Garden City, NY: Doubleday, 1959).

45 Niklas Luhmann, Wie kann die moderne Gesellschaft sich auf ökologische Gefährdungen einstellen? (Opladen: Vorträge G 278 der Rheinisch-Westfälischen Akademie der Wissenschaften, 1985).

46 Luhmann, "Biographie, Attitüden, Zettelkasten", p. 144.

47 This is similar to the section containing his thoughts on his filing system, which was probably created in the course of preparing the article about his card index, which was published in 1981. Cf. Luhmann, "Kommunikation mit Zettelkästen".

EBSCO : eBook Collection (EBSCOhost) - printed on 3/13/2019 4:08 AM via UNIVERSITÄT BIELEFELD 
requests and, in this way, would affect the (then emerging) publications. In the process, he would also document the evolution of his thought process and theory developments over the course of producing these publications. One can identify sets of entries that were added to the file that can be associated with a number of his publication projects since the mid-1970s without these publications representing simple copies of these sections of the file, as the system of references contained therein always pointed to other parts beyond the section in question: "On given occasions, the file provides combinatory options that were never planned, anticipated, or conceived in this way".48

To draw on the above-mentioned example of 'ecological communication' once again, the process of relating the subject areas to one another that were touched upon in the presentation (and others besides, such as resonance, observation, evolution) occurred only in the context of the book publication based on that presentation and which was (fairly quickly) completed three months later ${ }^{49}$ What this example clearly demonstrates is that the choice of which subject areas were ultimately related to one another was, apart from Luhmann's preference for relating heterogeneous issues, the particular outcome of the internal complexity of his filing system, generated by his system of referencing. However, the approximately 19o-page book considerably reduces that complexity again compared to the complexity of what is found in the filing cabinet. Among other things, this owes to limited space and the inevitably linear mode of presentation. To put it in positive terms, we might say that it requires the book form to make the complexity that is present in the file accessible - via reducing it by means of ultimately only being able to trace a select number out of all of the references available, whereas by its very nature there are no stops to this process of referencing in the file itself. Quite to the contrary, if we follow the web of references in detail that are laid down in the file, we constantly encounter new paths leading to new subjects, while the decision to pursue or ignore them presupposes that there is a specific question to be answered within a certain time; otherwise, one risks getting lost in the depths of the file. This, however, was not the intention of its creator, to whom the file was not a maze but a thinking tool, a communication partner, and a publication machine.

\footnotetext{
48 Luhmann, “Kommunikation mit Zettelkästen", p. 226.

49 Niklas Luhmann, Ökologische Kommunikation. Kann die moderne Gesellschaft sich auf ökologische Gefährdungen einstellen? (Opladen: Westdeutscher Verlag, 1986).
}

EBSCO : eBook Collection (EBSCOhost) - printed on 3/13/2019 4:08 AM via UNIVERSITÄT BIELEFELD AN: 1368111 ; Cevolini, Alberto.; Forgetting Machines : Knowledge Management Evolution in Early Modern Europe 